\title{
PERTANGgUNGJAWABAN PIDANA PERBUATAN PENGGUNAAN MEREK YANG SAMA PADA POKOKNYA TANPA IZIN (Analisis Putusan MA.RI No. 2037/ Pid.Sus/2015)
}

\author{
Ibrahim Nainggolan \\ Universitas Muhammadiyah Sumatera Utara \\ Email; ibrahimnainggolan@umsu.ac.id
}

\begin{abstract}
Abstrak
Berdasarkan hasil penelitian dipahami bahwa Pengaturan hukum pidana mengenai perbuatan penggunan merek yang sama pada pokoknya di atur pada Bab XVIII Pasal 100-101 undang-undang No. 20 tahun 2016 tentang merek dan indikasi geografis perubahan atas undang-undang No. 15 tahun 2001 tentang merek. pertangungjawaban pidana terkait dengan tindak pidana yang penulis kaji, bahwa harusnya terdakwa dinyatakn melakukan sebuah tindak pidana karena merek yang dimiliki terdakwa berupa VIM KHO mengandung bahan pemutih yang sejatinya sama pada pokoknya dengan merek VIN KHO milik korban. Kebijakan hukum pidana (penal police) terkandung di dalamnya tiga kekuasaan/kewenangan, yaitu kekuasaan legislatif/formulatif berwenang dalam hal menetapkan atau merumuskan perbuatan apa yang dapat dipidana yang berorientasi pada permasalahan pokok dalam hukum pidana meliputi perbuatan yang bersifat melawan hukum, kesalahan/pertanggungjawaban pidana dan sanksi apa yang dapat dikenakan oleh pembuat undang-undang. Dengan demikian diperhatikannya tahap ini mampu mengimbangi perkembangan kejahatan ataupun tindak pidana merek, kebijakan hukum pidana yang di buat legislatif melalui undang-undang yang di terbitkannya mampu mencegah peluku tindak pindana merek, baik itu pada peningkatan hukuman maupun pada perluasn terhadap tindak pidana merek. Tahap aplikasi oleh aparat penegak hukum atau pengadilan, dan tahapan eksekutif/administratif dalam melaksanakan hukum pidana oleh aparat pelaksana/eksekusi pidana. Dalam tahap ini kita dapat melihat bahwa penerapan hukum oleh aparat penegak hukum terkait dengan tindak pidana merek haruslah melihat fakta-fakta dilapangan, dengan demikian penegakan hukum terhadap merek dapat menjadi lebih baik. Terkait dengan hal demikian, kebijakan hukum non penai juga sagat menentukan dalan perkembangan hukum merek di indonesia, hal ini dapat kita perhatikan dari efektifitas pencegahan yang dilakukan oleh aparatur penegak hukum dalam mengurangi kejahatan merek.
\end{abstract}

Kata kunci:Pertanggungjawaban Pidana, Merek yang Sama,Tanpa Izin.

\section{PENDAHULUAN}

Hak Kekayaan Intelektual merupakan hak atas suatu ciptaan, baik karya seni, teknologi, atau buah pemikiran yang bersifat pribadi pada pencipta karya tersebut serta tidak dapat dipungkiri keberadaannya. Karya seseorang harus dilindungi karena akan bermanfaat bukan hanya bagi dirinya, melainkan pada seluruh umat manusia ${ }^{1}$.

Hak kekayaan intelektual dilahirkan dengan pengorbanan tenaga, waktu, pemikiran, intuisi bahkan biaya, adanya pengorbanan tersebut menjadikan pengorbanan tersebut menjadikan karya yang dihasilkan memiliki nilai. Apabila ditambah dengan manfaat ekonomi yang dapat dinikmati, nilai ekonomi yang melekat menumbuhkan konsep kekayaan terhadap karya-karya intelektual. ${ }^{2}$

Hak kekayaan intelektual merupakan hak privat, yaitu seseorang bebas untuk mengajukan permohonan atau pendaftaran karya intelektualnya untuk mendapat perlindungan atau tidak. Hak eksklusif yang diberikan negara kepada pencipta atau pemegang hak terkait dimaksudkan sebagai penghargaan atas hasil kreativitasnya serta agar orang lain terangsang untuk mengembangkan lebih lanjut. ${ }^{3}$

Indonesia sebagai bagian dari masyarakat internasional melalui Undang-undang Nomor 7 Tahun 1994 telah mengesahkan Persetujuan Tentang Pembentukan Organisasi Perdagangan Dunia yang terbentuk melalui persetujuan tentang tarif perdagangan.

Pengesahan tersebut didasari kesadaran adanya peluang dan tantangan yang timbul karena kemajuan ilmu pengetahuan, teknologi dan informasi yang telah mampu menerobos batasan-batasan

1 Adrian Sutedi, Hak Atas Kekayaan Intelektual. Sinar Grafika,Jakarta,2013Halaman5.

2 Tim Visi Yustisia, Panduan Resmi Hak Cipta dari Mendaftar, Melindungi, hingga Menyelesaikan Sengketa. Visimedia, Jakarta 2015Halaman 44.

${ }^{3}$ Ibid., Halaman 45. 
negara, berikut perangkat sosial, budaya, ekonomi dan hukumnya. ${ }^{4}$ Perjanjian tentang aspek-aspek perdagangan HKI meliputi:
1. Hak Cipta;
2. Hak Merek;
3. Indikasi geografis;
4. Desain industri;
5. Paten;
6. Tata Letak Sirkuit Terpadu;
7. Perlindungan informasi rahasia;
8. Kontrol praktek persaingan usaha tidak sehat dalam perjanjian lisensi. ${ }^{5}$

Berdasarkan aspek-aspek HKI tersebut, terdapat Hak Merek yang aturan hukumnya di Indonesia diatur dalam Undang-undang Nomor 15 Tahun 2001 tentang Merekdan diubah dengan undang-undang No 20 Tahun 2016 menjadi Undang-undang Merek dan Indikasi Geografis(selanjutnya disebutUndangundang Merek).Hak Merekdalam hal ini merupakan bagian hak milik intelektuallainnya yang selalu berkembangmengikuti perkembangan zaman sangat dipengaruhi oleh faktor-faktor sosial, ekonomi dan teknologi,karenasemakin majunya teknologi suatu negara semakin canggih pula pelanggaran dilakukan.

Merek adalah tanda berupa gambar, nama, kata, huruf, angka-angka, susunan, atau kombinasi dari unsur-unsur tersebut yang memiliki daya pembeda dan di gunkan dalam kegiatan perdagangan barang dan jasa. Merek merupakan suatu tanda pembeda atas barang atau jasa bagi satu perusahaan dengan perusahaan lainnya. Sebagai tanda pembeda maka merek dalam suatu klarifikasi barang/jasa tidak boleh memiliki persamaan antara satu dan lainnya, baik pada keseluruhan maupun pada pokonya.Pengertian persamaan pada keseluruhannya yaitu apabila memiliki persamaan dalam hal asal, sifat, cara pembuatan, dan tujuan pemakaiannya. Sedangkan pengertian persamaan pada pokoknya yaitu apabila memiliki persamaan pada persamaan bentuk, persamaan cara penempatan, persamaan bentuk dan cara penempatan, persamaan bunyi ucapan. ${ }^{6}$

Salah satu perkembangan yang aktual dan memperoleh perhatian yang seksama dalam masa sepuluh tahun terakhir ini dan kecenderungan yang masih akan berlangsung di masa yang akan datangadalah semakin meluasnya arus Globalisasi, baik di bidang sosial, ekonomi, budaya maupun di bidang-bidang kehidupan lainnya. Perkembangan teknologi informasi dan transportasi tela menjadikan kegiatan di sektor perdagangan meningkat secara pesat bahkan telah menempatkan dunia sebagai pasar tunggal bersama.

Era perdagangan global hanya dapat di pertahankanjika terdapat iklim persaingan usaha yang sehat. Di sini merek memegang peranan yang sangat pentingyang memerlukan sistem peraturan yang memadai. Berdasarkan pertimbangan tersebut dan sejalan dengan perjanjian-perjanjian internasional yang telah diratifikasi oleh indonesia serta pengalaman melaksanakan admnistrasi merek, penyempurnaan undang-undang merek yaitu undang-undang No 19 tahun 1992 (Lembaran Negara Tahun 1992 Nomor 81) sebagaimana diubah dengan undang-undang No 14 Tahun 1997(Lembaran Negara Tahun 1997 Nomor 31) sebagaimana diubah dengan Undang-undang Nomor 15 Tahun 2001 tentang Merek dan diubah dengan undang-undang No 20 Tahun 2016 tentang Merek menjadi undang- undang Merek dan Indikasi Geografis (selanjutnya disebut Undang-undang Merek). ${ }^{7}$

KonsultanHak KekayaanIntelektual yaitu Mudiardjo menjelaskan bahwa, Saat perusahaan tersebut menjual produk barang dan/atau jasa, perusahaan tersebut harus mendaftarkan mereknya berdasarkan kelas barang maupun jasanya. ${ }^{8}$

Undang-undang No. 20 tahun 2016 padaPasal 1 (ayat 1) disebutkan pengertian merek adalah tanda yang dapat di tampilkan secara Grafis berupa gambar, logo, nama, kata, huruf, angka, susunan warna, dalam bentuk 2(dua) dimensi dan/atau 3 (tiga) dimensi, suara hologram atau kombinasi dari 2 (dua) atau lebih unsur tersebut untuk membedakan barang dan/atau jasa yang di produksi oleh orang atau badan hukum dalam kegiatan perdagangan barang dan/atau jasa.

4 Rahmi Jened Painduri Nasution, Interface Hukum Kekayaan Intelektual dan Hukum Persaingan Penyalahgunaan HKI. PT. Raja Grafindo Persada, Jakarta, 2015,Halaman 3.

5 Tim Lindsey, dkk (ed), Hak Kekayaan Intelektual Suatu Pengantar. PT Alumni,Bandung, 2011Halaman 3.

${ }^{6}$ Adrian Sutedi. Op.Cit Halaman 91.

${ }^{7}$ Ibid. Halaman 89-90.

8 Anonym, “Apakah Logo Terdaftar Perusahaan Otomatis Menjadi Merek”, Melalui www.hukumonline.com, diakses Minggu, 5 Maret 2017, Pukul 22.55 wib. 
Hak atas merek adalah hak khusus yang di berikan pemerintah kepada pemilik merek, untuk menggunakan merek teresebut atau memberikan izin untuk menggunakannya kepada orang lain, merek sangatlah penting dalam dunia pemasaran dan periklanan karena publik sangat sering mengaitkan suatu imejt, kualitas, reputasi barang barang dan jaa dengan meek tertentu.

Merek dapat menjadi kekayaan yang sangat berharga secar komersial dan merek suatu perusahaan seringkali lebih bernilai dari aset rill perusahaan tersebut. Merek juga berguna bagi para konsumen bahkan membeli suatu produk tertentu di lihat dari mereknya, karena menurut mereka merek tersebut berkualitas tinggi atau aman utuk dikonsumsi di karenakan reputasi dari merek tersebut. Jika sebuah perusahaan menggunakan merek dari perusahaan lain, maka para konsumen mungkin merasa tertipu karena membeli produk dengan kualitasyang lebih rendah. ${ }^{9}$

Berdasarkan hal tersebut, merek haruslah menjadi perhatian bagi pemerintah guna mendukung perkembangan ekonomi nasional dan internasional, mengingat bahwa negara indonesia merupakan negara yang banyak di lirik oleh pengusaha pengusaha nasional dan internasional, oleh sebab itu perlindungan yang baik akan merek merupakan langkah kongkrit pemerintah dalam menunjang perkembangan ekonomi nasional.

Saat ini, kita melihat banyak merek dagang yang beredar di pasar nasional yangantara satu merek dengan merek lainnya memiliki persamaan, baik itu persamaan pada keseluruhan maupun persamaan pada pokonya, dan ini merupakan perbuatan yang jelas merugikan Negara dan pengusaha pemegang hak merek tersebut.

Berdasarkan hal tersebut, terkait merek yang merupakan bentuk dari ciptaan seseorang yang harus dilindungi karena merek merupakan kekayaan intelektual yang mempunyai arti ekonomis bagi pencipta. merek ini tidak luput pula dari perbuatan-perbuatan yang mana objek tersebut dapat dipergunakan oleh pihak lain, baik itu Persamaan pada pokoknya ataupun persamaan pada keseluruhannya dimana pelanggaran yang terjadi dalam hak merekatas merek adalah penggunaan tanpa izin. Perbuatan ini dapat merugikan pemegang hak merekatas merek yang dipergunakan tersebut.

Berbicara mengenai pertanggungjawaban pidana, berarti berbicara mengenai orang yang melakukan perbuatan pidana. Pelanggaran merek yang telah di putus oleh Mahkamah Agung Republik Indonesia dalam putusan Nomor 2037/Pid.Sus/2015 merupakan pelanggaran merek dalam ketentuan hukum pidana. ${ }^{10}$ Pelanggaran merek terdaftar dalam putusan ini pada pokoknya adalah perbuatan dengan sengaja dan tanpa hak menggunakan merek yang sama pada pokoknya dengan merek terdaftar milik pihak lain untuk barang atau jasa sejenis yang diproduksi dan atau diperdagangkan.

Pelanggaran merek terdaftar ini terjadi dengan uraian singkat, dimana terdakwa EDY PURWANTO SIREGAR pada hari Jumat tanggal 08 Juli 2005 sekira pukul 10.00 WIB atau setidaknya pada waktu lain dalam tahun 2005 bertempat di Pajak/Pasar Pagi Mandala atau Pajak Pekong Medan serta di Swalayan Maju Bersama Glugur di Jalan Yos Sudarso No. 125 Medan, atau setidaknya di suatu tempat lain yang masih termasuk dalam daerah hukum Pengadilan Negeri Medan, dengan sengaja dan tanpa hak menggunakan merek yang sama pada keseluruhannya dengan merek yang terdaftar milik pihak lain untuk barang dan/atau jasa sejenis yang diproduksi dan/atau diperdagangkan, yang dilakukan Terdakwa dengan cara-cara antara lain sebagai berikut:

Awalnya, pada waktu dan tempat tersebut di atas, saksi Rizal menjajakan produk pemutih pakaian merek Vinkho ke Pajak/Pasar Pagi Mandala atau Pajak Pekong Medan, saksi melihat produk pemutih pakaian yang hampir sama dengan produk pemutih pakaian merek Vinkho yaitu produk pemutih pakaian merek Vim Kho, bahwa produk pemutih pakaian merek Vinkho telah terdaftar di Kantor merek dengan Sertifikat Nomor : 55559997 Kelas 03 untuk jenis barang pembersih lantai dan pemutih pakaian. saksi Rizal merasa merek Vinkho adalah miliknya dan saksi Rizal tidak pernah memberi ijin kepada pihak lain untuk memproduksi merek serupa dan jenis barang pemutih pakaian, kemudian saksi Rizal mencari informasi dan mendapat informasi bahwa pemasok atau pemilik barang pemutih pakaian merek Vim Kho adalah Terdakwa EDY PURWANTO SIREGAR yang beralamat di Jalan Peringgan (dahulu Jalan Lembaga) No. 86 Dusun Tanjung Rejo, Kecamatan Percut Sei Tuan, Kabupaten Deli Serdang, serta saksi juga melihat produk pemutih pakaian merek Vim Kho dijual di Swalayan Maju Bersama Glugur di Jalan Yos Sudarso No. 125 Medan. Selanjutnya diketahui bahwa merek Vim Kho milik Terdakwa EDY PURWANTO SIREGAR ditolak untuk jenis barang sediaan-sediaan pemutihan sesuai dengan Sertifikat Nomor : 335057." 11

${ }^{9}$ Tim Lindesey.Op.Cit . Halaman 131-132.

${ }^{10}$ Tim Redaksi Tatanusa, Himpunan Putusan-Putusan Mahkamah Agung Dalam Perkara Hak Kekayaan Intelektual, Tatanusa, Jakarta, Halaman 177.

11 Putusan MA. RI 2037/Pid.Sus/2015 
Ketentuan hukum pidana masih sangat berfungsi dalam perlindungan merek terdaftar di Indonesia. Karena tujuan dijatuhinya seseorng pelanggar merek sanksi pidana yaitu agar menimbulkan deterence efec baik terhadap pelaku perbuatan pelanggaran merek terdaftar maupun terhadap masyarakat pada umumnya agar tidak ikut serta atau mencotoh perbuatan pelanggaran merek terdaftar karena adanya sanksi pidana.

\section{Metode Penelitian}

a. Jenis dan Sifat Penelitian

Jenis penelitian yang dipergunakan dalam penelitian ini adalah penelitian hukum normatif. Penelitian hukum normatif adalah penelitian yang dilakukan dengan cara meneliti bahan pustaka (data sekunder) atau penelitian hukum kepustakaan. ${ }^{12}$ Penelitian hukum normatif merupakan suatu prosedur penelitian ilmiah untuk menemukan kebenaran berdasarkan logika keilmuan hukum dari sisi normatifnya. Logika keilmuan yang sering dalam penelitian hukum normatif yaitu ilmu hukum yang objeknya hukum itu sendiri. ${ }^{13}$ Penelitian hukum normatif terdiri dari. ${ }^{14}$

a. Asas hukum regulatif (yang sejajar dengan pembedaan menjadi asas hukum umum dan asas hukum khusus).

b. Asas hukum konsitutif merupakan asas-asas yang harus ada dalam kehidupan suatu sistem hukum.

Penelitian ini bertujuan mengungkapkan kenyataan sampai sejauh mana suatu perundangundangan tertentu serasi secara vertical dan horizontal dengan suatu aturan lain, sehingga terjadi singkronisasi hukum.

Penelitian dalam tesis ini adalah bersifat deskriptif analisis. ${ }^{15}$ Penelitian yang bersifat deskriptif analisis merupakan suatu penelitian yang mengambarkan, menelaah, menjelaskan dan menganalisis suatu peraturan hukum. ${ }^{16}$ Penelitian ini merupakan suatu kegiatan ilmiah yang didasarkan pada metode, sistematika dan pemikiran tertentu yang bertujuan untuk mempelajari suatu hukum tertentu dengan jalan menganalisanya. ${ }^{17}$

b. Alat Pengumpulan Data

Pengumpulan data dalam penelitian ini dilakukan dengan studi dokumen dimana seluruh data sekunder yang dipergunakan dalam penelitian ini, dikumpulkan dengan mempergunakan studi dokumen, pada tahap awal pengumpulan data, dilakukan inventaris seluruh data dan atau dokumen yang relevan dengan topik pembahasan, selanjutnya dilakukan pengkategorian data-data tersebut berdasarkan rumusan masalah yang telah ditetapkan. Data tersebut selanjutnya dianalisis dengan metode analisis yang telah dipilih. $^{18}$

c. Analisis Data

Analisis data adalah suatu proses mengatur urutan data, membuatnya ke dalam suatu pola, kategori, dan suatu uraian dasar. ${ }^{19}$ Analisis data dalam penelitian ini menggunakan secara kualitatif, yaitu didasarkan pada relevansi data dengan permasalahan, bukan berdasarkan banyaknya data (kuantitatif). ${ }^{20}$ Analisis kualitatif ini dengan norma-norma, asas-asas, prinsip-prinsip, konsep-konsep, doktrin-doktrin ${ }^{21}$

Menganalisis data sekaligus memberikan argumentasi-argumentasi yuridis yang dikemukakan secara deduktif (penalaran logika dari umum ke khusus). ${ }^{22}$ Analisis berdasarkan logika deduktif sering disebut sebagai cara berfikir analitik, bertolak dari pengertian dari sesuatu yang berlaku umum secara keseluruhan dalam perundang-undangan terhadap suatu kelompok tertentu dalam suatu peristiwa tertentu

${ }^{12}$ Ediwarman, Monograf Metode Penelitian Hukum, edisi ke II, Medan, 2009, Halaman 24.

${ }^{13}$ Jhonny Ibrahim, Teori Dan Metedologi Penelitian Hukum Normatif, Pustaka Pelajar, Jakarta,2006 Halaman 57.

${ }^{14}$ Ediwarman,Op., Cit, Halaman 30.

${ }^{15}$ Bambang Waluyo. 1996. Penelitian Hukum Dalam Praktek, Jakarta: Sinar Grafika, Halaman8.

${ }^{16}$ Soerjono Soekamto., Op., Cit, Halaman6.

17 Soerjono Soekamto dan Sri Mamudji. 1995. Penelitian Hukum Normatif Suatu Tinjauan Singkat, Jakarta: RajaGrafindo Persada, Halaman43.

${ }^{18}$ Munir Fuady. Dinamika Teori Hukum, Jakarta: GHalamania Indonesia, 2007, Halaman6.

${ }^{19}$ Lexy J.Moleong, Metodologi Penelitian Kualitatif,PT. Remaja Rosda Karya, Bandung, 2004 Halaman 103.

${ }^{20}$ Johny Ibrahim, Op. Cit, Halaman 161.

${ }^{21}$ Ibid., Halaman 306 dan 310-311.

${ }^{22}$ Ibid., Halaman 393. 
dan dalam suatu wilayah tertentu. ${ }^{23}$ Hasil akhir dari analisis ini adalah penarikan kesimpulan dari perumusan masalah yang bersifat umum (dalam perundang-undangan) terhadap permasalahan kongkrit (dalam rumusan masalah) dengan menjelaskan hubungan antara berbagai jenis data sehingga permasalahan akan dapat dijawab. ${ }^{24}$

Adapun proses analisis data dilakukan sebabagi berikut:

a. Dilakukan inventarisasi terhadap perundang-undangan yang relevan untuk menjawab permasalahan penelitian.

b. Dilakukan abstraksi untuk menemukan makna atau konsep-konsep yang terkandung dalam bahan hukum (konsep kualisasi).

c. Mengelompokan konsep-konsep yang sejenis atau berkaitan (kategorisasi).

d. Menemukan hubungan antara berbagai ketegori yang diuraikan dan dijelaskan, penkelasan ini dilakukan dengan menggunakan prespektif teoritis para sarjana.

Penarikan kesimpulan dalam tulisan ini dilakukan dengan menggunakan logika berfikir deduktifinduktif yaitu dilakukan dengan teori yang digunakan sebagai titik tolak untuk melakukan penelitian. Dengan demikian teori digunakan sebagai alat, ukuran dan intrumen atau sebagai pisau analisis dalam melihat permasalahan terhadap Pertanggungjawaban Pidana Terhadap Perbuatan Pengunaan Merek yang Sama Pada Pokoknya Tanpa Izin. (Analisis Putusan MA. RI Nomor: 2037/Pid.Sus/2015).

\section{HASIL PENELITIAN dan PEMBAHASAN}

1. Pengaturan Hukum Pidana Mengenai Perbuatan Penggunaan Merek Yang Sama Pada Pokoknya.

a. Undang-undang No 20 tahun 2016.

Dalam catatan statistik Direktorat Jendral Kekayaan Intelektual (DITJEN KI), Merek merupakan kekayaan Intelektual yang paling sering didaftarkan untuk dimintakan perlindungannya oleh masyarakat bisnis. Para pelaku bisnis di Indonesia, mulai dari UMKM sampai dengan Perusahaan TBK, sudah mulai menyadari betapa pentingnya perlindungan hak atas Merek. ${ }^{25} \mathrm{Hal}$ tersebut tidak terluput dari betapa pentingnya Merek terhadap kemajuan perusahaan.

Pembangunan suatu citra Merek bukanlah hal yang mudah. Dalam prosesnya, perusahaan melakukan promosi secara besar-besaran dan membuat produk dengan kualitas yang baik secara konsisten agar dapat menghasilkan suatu citra Merek yang kuat dan positif. Ketika citra Merek tersebut terbentuk maka citra yang melekat di masyarakat akan cenderung sulit diubah.

Citra Merek yang kuat dan positif menjadi magnet bagi segelintir orang untuk mendapatkan keuntungan dengan cara yang ilegal. Keuntungan tersebut didapatkan dengan menggunakan Merek tanpa seizin pemilik Merek ataupun dengan menjual produk yang memiliki nama Merek yang serupa tetapi tidak sama. Akibatnya, baik pemilik merek maupun konsumen dapat mengalami kerugian. Kerugian yang didapatkan oleh konsumen adalah Konsumen mendapatkan barang-barang palsu dengan kualitas rendah, sedangkan untuk pemilik Merek, secara otomatis akan mengalami penurunan penjualan

Pemerintah sudah sejak lama memberikan perhatian terhadap isu pelanggaran Merek di Indonesia. Hal ini dibuktikan dengan adanya Undang-undang Merek yang sudah lama berlaku di Indonesia. Bahkan di tahun 2016, pemerintah kembali merilis Undang-undang No. 20 tahun 2016 tentang Merek dan indikasi gegrafismenggantikan Undang-undang No. 15 tahun 2001 tentang merek. Kehadiran Undang-undang No. 20 tahun 2016 tentang Merek dan indikasi gegrafisadalah untuk menyempurnakan perlindungan kepada pemilik Merek dan juga memberikan penyesuaian terhadap perkembangan kekayaan intelektual di Indonesia.

Ada beberapa perbedaan yang cukup mendasar antara Undang-undang No. 20 tahun 2016 tentang Merek dan indikasi gegrafis dengan undang-undang Merek 2001. Perbedaan pertama terdapat pada penamaan dari Undang-undang tersebut. Apabila pada undang-undang Merek 2001 hanya disebutkan dengan Undang-undang tentang Merek, pada Undang-undang No. 20 tahun 2016 tentang Merek dan indikasi gegrafisdisebutkan Undang-undang Merek dan Indikasi Geografis.

Penyebutan Indikasi Geografis pada penamaan Undang-undang No. 20 tahun 2016 tentang Merek dan indikasi gegrafis bukanlah tanpa sebab. Apabila di dalam undang-undang Merek 2001 Indikasi Geografis hanya dibahas sedikit sekali dan cenderung lebih banyak dituangkan di dalam Peraturan Pemerintah, dalam Undang-undang No. 20 tahun 2016 tentang Merek dan indikasi gegrafis diuraikan lebih jelas dan tertuang di dalam empat BAB (Pasal 53 sampai dengan 71). Keempat BAB tersebut mengurai hal-hal terkait dengan pihak yang dapat memohon Indikasi Geografis (Lembaga yang mewakili

${ }^{23}$ Mukti Fajar N.D dan Yulianto Achmad. Dualisme Penelitian Hukum Normatif dan Empiris, Pustaka Pelajar, Yogyakarta, 2010, Halaman 109-110.

${ }^{24}$ Ibid., Halaman 109 dan Halaman 122.

${ }^{25}$ Ibid, Halaman 87. 
masyarakat di kawasan tertentu dan Pemerintah Daerah Provinsi atau Kabupaten Kota) dan Produk yang dapat dimohonkan (Sumber daya alam, Barang kerajinan tangan dan hasil industri dari masyarakat ataupun lembaga di kawasan geografis tertentu).

Selain terkait tentang Indikasi Geografis, perlindungan Undang-undang No. 20 tahun 2016 tentang Merek dan indikasi gegrafis juga mencakup bentuk Merek. Jika sebelumnya dalam undang-undang Merek 2001, Merek yang dilindungi hanyalah Merek Konvensional berupa tanda yang berupa gambar, nama, kata, huruf-huruf, angka-angka, susunan warna, atau kombinasi dari unsur-unsur tersebut yang memiliki daya pembeda yang identik dengan logo dua dimensi. Undang-undang No. 20 tahun 2016 tentang Merek dan indikasi gegrafis memperluas bentuk Merek yang dapat didaftarkan, di antaranya adalah Merek 3 dimensi, Merek suara dan Merek Hologram. ${ }^{26}$

Upaya pembaruan lainnya yang dibawa di dalam Undang-undang No. 20 tahun 2016 tentang Merek dan indikasi gegrafis adalah proses pendaftaran Merek yang menjadi lebih singkat. Percepatan tersebut terjadi pada masa pemeriksaan Substantif yang dipersingkat menjadi 150 hari, sebelumnya 9 bulan dan masa pengumuman Merek yang menjadi 2 bulan, sebelumnya 3 bulan. ${ }^{27}$ Selain itu, pada undang-undang Merek 2001 proses pendaftaran lebih lama karena pengumuman dilakukan setelah pemeriksaan substantif Merek dilakukan, sedangkan pada Undang-undang No. 20 tahun 2016 tentang Merek dan indikasi gegrafis, pengumuman dilakukan sebelum pemeriksaan Substantif dilakukan. Sehingga apabila terdapat pihak yang keberatan terhadap Merek yang akan didaftarkan tersebut maka dapat terdeteksi lebih awal sebelum Merek memasuki proses yang lebih lama lagi.

Dalam Undang-undang No. 20 tahun 2016 tentang Merek dan indikasi gegrafis, Menteri memiliki hak untuk menghapus Merek terdaftar dengan alasan Merek tersebut merupakan Indikasi Geografis. Wewenang tersebut diberikan kepada menteri untuk memfasilitasi masyarakat banyak apabila terjadi pelanggaran Indikasi Geografis. Meskipun demikian, pemilik Merek yang haknya dihapuskan oleh menteri tetap memiliki upaya untuk mempertahankan Hak atas Merek miliknya melalui gugatan ke PTUN.

Poin lain yang difasilitasi oleh Undang-undang No. 20 tahun 2016 tentang Merek dan indikasi gegrafis adalah terkait gugatan yang dapat dilakukan oleh Merek terkenal. Meskipun di dalam undang-undang tersebut klasifikasi Merek terkenal masih di dalam garis abu-abu, suatu Merek dapat dinyatakan terkenal atau tidak melalui putusan Pengadilan. Sehingga setelah diakui sebagai Merek terkenal, pemilik Merek tersebut dapat mengajukan gugatan terhadap pihak yang tanpa hak menggunakan Merek yang mempunyai persamaan pada pokoknya atau keseluruhannya untuk barang dan/atau jasa yang sejenis. ${ }^{28}$

Pemberatan sanksi pidana merupakan hal yang baru di dalam Undang-undang No. 20 tahun 2016 tentang Merek dan indikasi gegrafis Pemberatan tersebut berlaku untuk Merek yang produknya dapat mengancam lingkungan hidup, keselamatan dan kesehatan jiwa manusia. Maka undang-undang mengatur bahwa jika Merek tersebut dipergunakan secara tanpa Hak dan tidak bertanggung jawab. ${ }^{29}$ Maka pihak yang mempergunakan secara tanpa hak mendapatkan pemberatan sanksi pidana.

Keseriusan pemerintah dalam melindungi kekayaan intelektual di Indonesia sudah dibuktikan dengan menyempurnakan peraturan hukum yang berlaku, memperbaiki birokrasi dan juga melindungi para pemangku kepentingan yaitu pemilik Kekayaan Intelektual. Kekayaan Intelektual yang sangat dekat dan tidak dapat lepas dari semua industri di Indonesia, terutama industri kreatif yang sedang berkembang di era teknologi seperti saat ini, seharusnya dapat semakin bertumbuh dan berkembang. Sehingga nantinya kekayaan bangsa ini dapat didominasi oleh kekayaan intelektual dan tidak lagi bergantung kepada kekayaan alam.

Oleh sebab itu, Undang-undang No. 20 tahun 2016 tentang Merek dan indikasi gegrafis merupakan salah satu jawaban untuk dapat memajukan Kekayaan Intelektual di Indonesia.

Lahirnya undang-undang tersebut seyogyanya dimanfaatkan dengan baik oleh para pengusaha ataupun pemilik produk untuk memiliki kepercayaan diri dalam mengembangkan produk yang dimilikinya. Sehingga dengan adanya kepastian hukum terhadap perlindungan dan percepatan di dalam pendaftaran dan kepemilikan Kekayaan Intelektual. Masyarakat dapat terus mengeksplorasi

\footnotetext{
${ }^{26}$ Tim Visi Yustisia, Panduan Resmi Hak Cipta, Visi Media, Jakarta, 2015, Halaman 88.

${ }^{27}$ Ibid, Halaman 91.

${ }^{28}$ Adil sumadani, Dasar-Dasar Hukum Bisnis, Mitra Wacana Media, jakarta, 2013, Halaman 57.

${ }^{29}$ Ibid, Halaman 61.
} 
Kekayaan Intelektual miliknya sehingga memiliki nilai ekonomi yang dapat mendorong pembangunan perekonomian nasional. ${ }^{30}$

b. Aturan Hukum Terkit Merek Selain undang-undang.

Peraturan Menteri Hukum dan HAM Nomor 67 Tahun 2016 tentang Pendaftaran Merek ini mulai diberlakukan terhitung sejak Januari 2017. Peraturan Menteri Hukum dan HAM (Permenkumham) ini merupakan pelaksanakan ketentuan Pasal 6 ayat (3), Pasal 8, Pasal 21 ayat (4), Pasal 27 ayat (3), Pasal 39 ayat (3), Pasal 40 ayat (4), Pasal 41 ayat (9), dan Pasal 51 Undang-undang Nomor 20 Tahun 2016 tentang Merek dan Indikasi Geografis.

\section{c. Bentuk -Bentuk Tindak Pidana Merek.}

1. Peniruan merek dagang

Pengusaha yang beriktikad tidak baik tersebut dalam hal persaingan tidak jujur semacam ini berwujud penggunaan upaya- upaya atau ikhtiar-ikhtiar mempergunakan merek dengan meniru merek terkenal (well know trade mark) yang sudah ada sehingga merek atas barang atau jasa yang diproduksinya secara pokoknya sama dengan merek atas barang atau jasa yang sudah terkenal (untuk barang-barang atau jasa sejenis) dengan maksud menimbulkan kesan kepada khalayak ramai, seakan-akan barang atau jasa yang diproduksinya itu sama dengan produksi barang atau jasa yang sudah terkenal itu.

Dalam hal ini dapat diberikan contoh, bahwa dalam masyarakat sudah dikenal dengan baik sabun mandi dengan merek "Lux" kemudian ada pengusaha yang memproduksi sabun mandi merek "Lax". Tentunya pengusaha ini berharap bahwa dengan adanya kemiripan tersebut ia dapat memperoleh keuntungan yang besar tanpa mengeluarkan biaya besar untuk promosi memperkenalkan produksinya tersebut. Hal ini karena konsumen dapat terkelabui dengan kemiripan merek tersebut.

2. Praktek pemalsuan merek dagang

Adalah suatu bentuk, proses atau cara perbuatan pemalsuan tujuanya adalah untuk mendapatkan keuntungan, dimana kejahatan di bidang merek merupakan salah satu dari aktifitas persaingan usaha tidak sehat.

Banyak sekali pemalsuan merek terjadi seperti misall kasus pemalsuanProduk Milk Bath merek the Body Shop di Jakarta yang mana awal mulanya banyak konsumen yang mengeluh mengenai kualitas produk ini yang berbeda dengan yang biasanya dipakai, yang mana setelah di tindaklanjuti terdapat merek yang hampir sama dengan Produk Milk Bath, dan masih banyak lagi kasus kasus pemalsuan yang terjadi. ${ }^{31}$

3. Perbuatan-perbuatan yang Dapat Mengacaukan Publik

Berkenaan Dengan Sifat dan Asal Usul Merek Hal ini terjadi karena adanya tempat atau daerah suatu negara yang dapat menjadi kekuatan yang memberikan pengaruh baik pada suatu barang karena dianggap sebagai daerah penghasil jenis barang yang bermutu.

Termasuk dalam persaingan tidak jujur apabila pengusaha mencantumkan keterangan tentang sifat dan asal-usul barang yang tidak sebenamya, untuk mengelabui konsumen, seakanakan barang tersebut memiliki kualitas yang baik karena berasal dari daerah penghasil barang yang bermutu misalnya mencantumkan keteranga made in England padahal tidak benar produk itu berasal dari Inggris. Seluruh perbuatan itu sangat merugikan pemilik merek. Karena akibat dari persaingan tidak jujur (pemalsuan dan peniruan merek terkenal) akan mengurangi omzet penjualan sehingga mengurangi keuntungan yang sangat diharapkan dari mereknya yang lebih terkenal tersebut. ${ }^{32}$

Bahkan dapat menurunkan kepercayaan masyarakat terhadap merek tersebut, karena konsumen menganggap bahwa merek yang dulu dipercaya memiliki mutu yang baik ternyata sudah mulai turun kualitasnya.Bukan hanya itu saja, pelanggaran terhadap hak atas merekini juga sangat merugikan konsumen karena konsumen akan memperoleh barang-barang atau jasa yang biasanya mutunya lebih rendah dibandingkan dengan merek asli yang sudah terkenal tersebut, bahkan adakalanya produksi palsu tersebut membahayakan kesehatan dan jiwa konsumen. Mengapa timbulpraktek yang demikian itu, tentu tidak lain terbit juga dengan adanya fungsi merek itu sendiri.

2. Pertanggungjawaban Pidana Pada Tindak Pidana Merek.

30 Diakses Melalui: https://www.pphbi.com/2017/04/06/mengenal-lebih-dekat-undang-undangmerek-2016/. Pada hari jumat tanggal 23 januari 2018, pukul 20-00 WIB.

${ }^{31}$ Adami Chazawi, Tindak pidanan Hak Atas Kekayaan Intelektual (HAKI), Banyumedia, Malang,2007,Halaman 45.

${ }^{32}$ Ibid, Halaman 56. 
a. Penegakan Hukum Pidana

Sehubungan dengan Penegakan Hukum atas Pelanggran merek pada pokoknya maka perlu terlebih dahulu akan di jelaskan mengenai apa itu yang di mangsud dengan Penegakan hukum.

Penegakan adalah proses dilakukannya upaya untuk tegaknya atau berfungsinya norma-norma hukum secara nyata sebagai pedoman perilaku hubungan-hubungan hukum dalam kehidupan bermasyarakat dan bernegara sedangkan Pengertian tindak pidana sendiri adalah berasal dari istilah yang dikenal dalam hukum Pidana Belanda yaitu stafbaar feit. ${ }^{33}$

Strafbaar feit merupakan istilah asli bahasa Belanda yang diterjemahkan ke dalam bahasa Indonesia dengan berbagai arti diantaranya yaitu, tindak pidana, delik, perbuatan pidana, peristiwa pidana maupun perbuatan yang dapat dipidana. Kata Strafbaar feit terdiri dari 3 kata, yakni straf, baar dan feit. Berbagai istilah yang di gunakan sebagai terjemahan dari strafbaarfeit itu, straf di terjemahkan sebagai pidana dan hukum. Perkataan Baar diterjemahkan dengan dapat dan boleh, sedangkan untuk kata feit diterjemahkan dengan tindak, peristiwa, pelanggaran dan perbuatan. ${ }^{34}$

Sejalan dengan definisi atau pengertian menurut teori dan hukum positif, J.E Jonkers juga telah memberikan defenisi strafbaar feit menjadi dua pengertiaan, sebagaimana yang dikemukakan Bambang Pornomo yaitu. ${ }^{35}$

Definisi pendek memberikan pengertian "strafbaarfeit" adalah suatu kejadian (feit) yang dapat diancam Pidana oleh Undang - undang. Sedangkan Untuk Definisi panjang atau lebih dalam memberikan pengertian "strafbaarfeit" adalah suatu kelakuan yang melawan hukum dilakukan dengan sengaja atau alfa orang yang dapat dipertanggungjawabkan. Adapun penegakan hukum yang ada pada Undangundang Merek No 15 Tahun 2001 eliputi, Penegakan Hukum Administratif, Hukum Pidana serta Hukum perdata

Menurut Moeljatno tindak pidana adalah Perbuatan yang dilarang oleh suatu aturan hokum, larangan dengan disertai ancaman (sanksi) yang berupa pidana tertentu, bagi siapa yang melanggar larangan tersebut. ${ }^{36}$ Tindak Pidana di Bidang Merek adalah Suatu Perbuatan yang di larang dan di ancam hukuman sebagai kejahatan atau Pelanggaran sesuai dengan ketentuan dalam Undang-undang Merek.

Jadi di dalam tindak Pidana di bidang Merek objek hukumnya Berkaitan dengan HAKI khususnya merek. Tindak pidana akan melahirkan pertanggungjawaban pidana yang hanya dapat terjadi setelah sebelumnya seseorang melakukan tindak pidana, dimana pertanggungjawaban pidana dilakukan dengan asas yang berbeda yaitu dengan asas Tiada pidana tanpa kesalahan. Adapun dalam tindak pidana di kenal dua Unsur yaitu: Unsur subjektif adalah unsur-unsur yang melekat pada diri si pelaku atau yang berhubungan dengan diri si pelaku, dan termasuk ke dalamnya yaitu segala sesuatu yang terkandung di dalam hatinya. Adapun yang termasuk dalam Unsur Subjektif adalah :

1) Kesengajaan atau ketidaksengajaan (dolus atau Culpa).

2) Maksud atau Voornemen pada suatu percobaan atau pogging seperti yang dimaksud dalam Pasal 53 ayat $1 \mathrm{KUHP}$.

3) Macam-macam maksud atau oogmerk seperti yang terdapat misalnya di dalam kejahatankejahatan pencurian, penipuan, pemerasan, pemalsuan dan lain-lain.

4) Merencanakan terlebih dahulu atau voorbedachte raad seperti yang terdapat di dalam

5) kejahatan pembunuhan menurut Pasal 340 KUHP.

6) Perasaan takut yang antara lain terdapat di dalam rumusan tindak pidana menurut

Pasal 308 KUHP.

Unsur objektif adalah unsur yang terdapat di luar diri pelaku tindak pidana. Unsur ini meliputi:

1) Sifat melanggar hukum atau wederrechtelicjkheid

2) Kualitas dari si pelaku,

misalnya kedaan sebagai seorang pegawai negeri di dalam kejahatan jabatan menurut Pasal 415 KUHP atau keadaan sebagai pengurus atau komisaris dari suatu Perseroan Terbatas di dalam kejahatan menurut Pasal 398 KUHP. Kausalitas yakni hubungan antara suatu tindak pidana sebagai penyebab dengan sesuatu kenyataan sebagai akibat

Ditinjau dari aspek hukum masalah merek menjadi sangat penting, sehubungan dengan persoalan perlu adanya perlindungan hukum dan kepastian hukum bagi pemilik atau pemegang merek dan perlindungan hukum terhadap masyarakat sebagai konsumen atas suatu barang atau

\footnotetext{
${ }^{33}$ Yusran Isnaini, $O p$, Cit Halaman 96.

${ }^{34}$ Adami Chazawi, Pengantar Hukum PidananBagian I, Garfindi, Jakarta, Halaman 69

${ }^{35}$ Bambang Poernomo, Asa-asas Hukum Pidana, GHalamania Indonesia, jakarta Halaman 91.

${ }^{36}$ Diakses Melalui: http://weloje.id/news-posts/poin-penting-undang-undang-no-20-tahun-2016tentang-merek-dan-indikasi-geografis-dan-pengetahuan-tentang-merek-terkenal/, Pada hari: Rabu, 24
} januari 2018. Pukul 14-30. 
jasa yang memakai suatu merek agar tidak terkecoh oleh merek-merek lain, tidak dapat dipungkiri lagi bahwa masalah penggunaan merek terkenal maupun tidak terkenal oleh pihak yang tidak berhak, masih banyak terjadi di Indonesia dimana masyarakat kita sering berpikir kurang ekonomis dan kurang inovatif. ${ }^{37}$

Perlindungan hukum merek yang diberikan baik kepada merek asing atau lokal, terkenal atau tidak terkenal hanya diberikan kepada merek yang terdaftar. Untuk itu setiap pemilik merek diharapkan agar mendaftarkan mereknya ke Dirjen Haki agar dapat memperoleh perlindungan hukum terhadap mereknya, perlindungan hukum yang di berikan kepada merek-merek yang telah terdaftar adalah untuk jangka waktu 10 (sepuluh) tahun tanggal penerimaan permohonan merek bersangkutan ( Pasal 28 undangundang Merek).

Atas permohonan pemilik merek jangka waktu perlindungan merek terdaftar dapat diperpanjang setiap kali untuk jangka waktu yang sama. Upaya meningkatkan perlindungan hukum yang lebih luas, berbagai macam upaya hukum telah dirancang sebagai sistem pelayanan perlindungan hukum kepada pemilik merek,tidak hanya sekedar tindakan administratif tetapi dapat juga dengan ancaman tuntutan pertanggung jawaban perdata maupun pertanggung jawaban pidana sebagaimana yang akan dikemukakan sebagai berikut. ${ }^{38}$

Proses dilakukannya upaya untuk tegaknya atau berfungsinya norma-norma hukum secara nyata sebagai pedoman perilaku dalam lalu blintas atau hubungan-hubungan hukum dalam kehidupan bermasyarakat dan bernegara. ${ }^{39}$ Dalam ketentuan pidana dibidang merek diatur dalam Bab XIV Pasal 90 Undang-undang Nomor 15 Tahun 2001 tentang merek yaitu “ Barang siapa dengan sengaja dan tanpa hak menggunakan Merek yang sama pada keseluruhannya dengan Merek terdaftar milik pihak lain untuk barang dan/atau jasa sejenis yang diproduksi dan/atau diperdagangkan, dipidana dengan pidana penjara paling lama 5 (lima) tahun dan/atau denda paling banyak Rp 1.000.000.000,00 (satu miliar rupiah)”.

Yang dimaksud dengan kata "tanpa hak" dalam Pasal 90 tersebut adalah merek yang digunakan "tidak terdaftar" dan sama pada keseluruhannya dengan merek terdaftar milik orang untuk barang dan/atau jasa sejenis.

Ini sesuai dengan sistem yang dianut dalam UNDANG-UNDANG Merek Nomor 15 Tahun 2001, yaitu sistem first to file ( hak atas merek di berikan pada pendaftar pertama )yang menentukan bahwa hak atas merek diberikan kepada pemilik merek terdaftar bukan kepada merek tidak terdaftar. Sedangkan yang dimaksudkan dengan barang atau jasa sejenis dalam Pasal 90 dijelaskan bahwa kelompok barang dan / atau jasa yang mempunyai persamaan dalam sifat, cara pembuatan, dan tujuan penggunaannya. ${ }^{40}$

b. Sanksi Pidana Pada tindak Pidana Merek.

Pasal 91 undang-undang No. 20 tahun 2016 tentang merek dan indikasi geografis perubahan atas undang-undang No. 15 tahun 2001 tentang merekyaitu bahwa " Barang siapa dengan sengaja dan tanpa hak menggunakan Merek yang sama pada pokoknya dengan Merek terdaftar milik pihak lain untuk barang dan/atau jasa sejenis yang diproduksi dan/atau diperdagangkan, dipidana denga pidana penjara paling lama 4 (empat) tahun dan/atau denda paling banyak Rp. 800.000.000,00 (delapan ratus juta rupiah)" apabila di rinci unsur-unsurnya maka "dengan sengaja ","tanpa hak mengunakan " Merek yang sama pada pokoknya dengan merek terdaftar milik pihak lain untuk barang dan jasa sejenis" dan pada Pasal 92 undang-undang No. 20 tahun 2016 tentang merek dan indikasi geografis perubahan atas undangundang No. 15 tahun 2001 tentang merekyaitu bahwa

1) Barangsiapa dengan sengaja dan tanpa hak menggunakan tanda yang sama pada keseluruhan dengan indikasi geografis milik pihak lain untuk barang yang sama atau sejenis dengan barang yang terdaftar,dipidana dengan pidana penjara paling lama 5 (lima) tahun dan/atau denda paling banyak Rp 1.000.000.000,00 (satu miliar rupiah).

2) Barangsiapa dengan sengaja dan tanpa hak menggunakan tanda yang sama pada pokoknya dengan indikasigeografis milik pihak lain untuk barang yang sama atau sejenis dengan barang yang terdaftar, dipidana dengan pidana penjara paling lama 4(empat) tahun dan/atau denda paling banyak Rp 800.000.000,00 (delapan ratus juta rupiah).

37 Philipus M Hadjono, Perlindungan hukum bagi HAKIdi indonesia edisi khusus penerbitan perdapan, 2007 Halaman 55.

38 Wiratmo,Dianggoro, Pembaharuan Undang-undang Merek dan dampak bagi dunia Bisnis, Jurnal Hukum Bisnis, Volume II, Halaman 53.

39 Diakses Melalui: https://wajib1969.files.wordpress.com/2013/10/makalah-hak-merk, Pada hari: Rabu, 24 januari 2018. Pukul 14-30.

${ }^{40}$ Diakses Melalui: https://wajibmerk, Pada hari: Rabu, 24 januari 2018. Pukul 14-30. 
3) Terhadap pencantuman asal sebenarnya pada barang yang merupakan hasil pelanggaran ataupun pencantuman kata yang menunjukkan bahwa barang tersebut merupakan tiruan dari barang yang terdaftar dan dilindungi berdasarkan indikasi Geografis, di berlakukan ketentuan sebagaimana dimaksud pada ayat (1) dan ayat ( 2 ).

Selanjutnya Pasal 93 Undang-undang Nomor 15 Tahun 2001 tentang merek yaitu bahwa Barang siapa dengan sengaja dan tanpa hak menggunakan tanda yang dilindungi berdasarkan indikasi-asal pada barang atau jasa sehingga dapat memperdaya atau menyesatkan masyarakat mengenai asal barang atau asal jasa tersebut, dipidana dengan pidana penjara paling lama 4 (empat) tahun dan/atau denda paling banyak Rp 800.000.000,00 (delapan ratus juta rupiah). ${ }^{41}$

Hukum Acara Pidana sebagai Hukum Formil dengan Ketentuan Khusus ( Lex Specialis ) Tentang Penyidikan pada undang-undang No. 20 tahun 2016 tentang merek dan indikasi geografis perubahan atas undang-undang No. 15 tahun 2001 tentang merek. Sistem Peradilan Pidana yang di gariskan KUHAP adalah sistem Terpadu Aktivitas, pelaksanaan criminal justice system merupakan fungsi gabungan (collection of function) dari: legislator, polisi, jaksa, pengadilan, dan penjara serta badan yang berkaitan baik di lingkungan pemerintahan maupun di luarnya.

Penyelesaian perkara merek juga mendasarkan pada sistem terpadu seperti yang digariskan KUHAP. Langkah penegakan hukum sangat tergantung pada kerjasama positif antara segenap aparat yang tertata baik dari tingkat penyidikan, penuntutan sampai pada pemutusan perkara. Hal ini pun menjadi pegangan pihak luar negeri untuk mengukur keberhasilan pelaksanaan sistem HAKI nasional, disamping upaya yang telah banyak dilakukan di bidang perbaikan legislasi. ${ }^{42}$

Berkaitan dengan Putusan Mahkamah Agung No. 2037/Pid.Sus/2015 yang menguatkan Putusan Pengadilan Negeri Medan Nomor 4636/Pid.B/2006/PN-Mdn. Terdakwa atas nama Edy Purwanto Siregar yang vonisnya menyatakan bebas dari segala tuntutan Jaksa Penuntut Umum.

Beradasarkan data yang telah dikumpulkan maka, untuk memastikan adanya persamaan pada pokoknya dalam sebuah merek antara merek Terdakwa "Vim Kho" dan merek pelapor "Vin Kho" sebagaimana mana berikut:

\begin{tabular}{|c|c|}
\hline Edy Prwanto Siregar (VIM KHO)/Terdakwa & Rizal (VIN KHO)/Pelapor \\
\hline $\begin{array}{l}\text { 1. Sebelum mendaftarkan Mereknya di DIRJEN } \\
\text { HAKI, Edy Purwanto Siregar telah } \\
\text { memproduksi pembersih dan pemutih merek } \\
\text { VIM KHO sejak tahun 1988. } \\
\text { 2. Edy Purwanto Siregar mendaftarkan mereknya } \\
\text { " VIM KHO " pada tanggal 09 Juni 1994 } \\
\text { dengan sertifikat No: } 335057 \text { dan di perpanjang } \\
\text { pada tanggal 05 November } 2004 \text { dengan } \\
\text { sertifikat No: 000013230 dengan Kelas barang } \\
\text { nomor 03 untuk jenis barang pembersih. } \\
\text { 3. Edi Purwanto Siregar mendaftarkan Merek } \\
\text { VIM KHO tersebut dengan jenis barang } \\
\text { pemutih, namun di tolak oleh DIRJEN HAKI, } \\
\text { karena memiliki Persamaan pada pokoknya } \\
\text { dengan merek lain. } \\
\text { 4. Penolakan tersebut berdasarkan sertifikat yang } \\
\text { di keluarkan oleh DIRJEN HAKI dengan } \\
\text { No.335057. } \\
\text { 5. Merek VIM KHO yang di daftarkan Edy } \\
\text { Purwanto Siregar merupakan kelas barang No.3 } \\
\text { dengan Kategori pembersih. }\end{array}$ & $\begin{array}{l}\text { 1. Sebelum mendaftarkan Mereknya di } \\
\text { DIRJEN HAKI, Rizal telah memproduksi } \\
\text { pemutih dengan MerekVIN KHO sejak } \\
\text { tahun 2001. } \\
\text { 2. Rizal mendaftarkan Mereknya pada tahun } \\
2003 \text { pada DIRJEN HAKI dengan No. } \\
55559997 \text { dengan kelas barang No.03 } \\
\text { untuk jenis barang Pemutih dan } \\
\text { pembersih. }\end{array}$ \\
\hline
\end{tabular}

Berdasarkan pemaparan di atas, secara perbandingan merek antara Terdakwa dengan Pelapor, maka dapat di simpulkan antara merek Vim Kho milik terdakwa dengan merek palapor Vinkho.

Walaupun dari segi pendaftaran, Terdakwa lebih dahulu melakukan pendaftaran dan mendapatkan sertifikat merek, tetapi pada sertifikat merek terdakwa tidak disebutkan secara jelas merek

${ }^{41}$ Undang-undang No 15 tahun 2001 tentng merek, bab XIV, Pasal 90-93.

42 Esti Ariani.,SH.,MH, Dosesn FH UNISRI, Pelanggaran Hak Atas Merek dan Mekanisme Penyelesaiannya di Indonesia, Halaman 124 
terdakwa kegunaanya sebagai pemutih pakaian tetapai hanya sebagai pembersih yang pada logika hukumnya sangat general atau bersifat umum, dikarenakan bisa saja sebagai pembersih lantai dan sebagainya. Atas dasar hal tersebut Dirjen HAKI menolak perpanjangan merek terdakwa menjadi barang pemutih dikarenakan telah ada merek tersebut yang terdaftar dan mendapatkan sertifikat merek yaitu merek Vin Kho milik pelapor.

Berdasarkan hal tersebut jelas terdakwa Edy Purwanto sewaktu mendaftarkan mereknya tidak mempunyai itikat baik, dikarenakan adanya unsur untuk mengambil keuntungan dengan membuat secara umum kegunaan merek yaitu pembersih, yang pada logikanya kalimat pembersih sangat general, bisa sebagai deterjen, bisa sebagai pewangi atau pemutih, tidak disebutkan sebagai spesifik atau secara spesialis.Berdasarkan hal tersebut terdakwa Edy Purwanto melanggarPasal 4, Pasal 5, dan Pasal 6 Undang-undang Nomor 15 tahun 2001 yang di ubah dengan undang-undang No 20 Tahun 2016 tentang Merek dan Indikasi Geogerfis di Jelaskan bahwa berdasarkan Pasal 4 Merek tidak dapat didaftar atas dasar Permohonan yang diajukan oleh Pemohon yang beritikad tidak baik.

Maksud beriktikad baik adalah Pemohon yang mendaftarkan Mereknya secara layak dan jujur tanpa ada niat apa pun untuk membonceng, meniru, atau untuk mendapatkan keuntungan yang besar dengan tujuan dapat membuat produk bermacam-macam ataumenjiplak ketenaran merek pihak lain demi kepentingan usahanya yang berakibat kerugian pada pihak lain itu atau menimbulkan kondisi persaingan curang, mengecoh, atau menyesatkan konsumen. Contohnya, Merek Dagang A yang sudah dikenal masyarakat secara umum sejak bertahun-tahun, ditiru demikian rupa sehingga memiliki persamaan pada pokoknya atau keseluruhannya dengan Merek Dagang A tersebut.

Dalam contoh itu sudah terjadi iktikad tidak baik dari peniru karena setidak-tidaknya patut diketahui unsur kesengajaannya dalam meniru Merek Dagang yang sudah dikenal tersebut. Sehingga dapat di ketahui berdasarkan pertimbangn hakim pada putusan Pengadilan Negri Medan No. 4636/Pid.B/2006/PN.Medan. bahwa Permohonan Pendaftaran Merek VIM KHO atas Merek VIN KHO sama sama tidak mengetahui tentang keberdaan kedua merek tersebut.

3. Kebijakan Hukum Dalam Tindak Pidana Perbuatan Penggunaan Merek Yang Sama Pada Pokoknya.

a. Kebijakan Hukum Penal (tindakan).

Istilah kebijakan berasal dari bahasa Inggris yakni Policy atau dalam bahasa Belanda Politiekyang secara umum dapat diartikan sebagai prinsip-prinsip umum yang berfungsi untuk mengarahkan pemerintah (dalam arti luas termasuk pula aparat penegak hukum dalam mengelola, mengatur, atau menyelesaikan urusan-urusan publik, masalah-masalah masyarakat atau bidang-bidang penyusunan peraturan perundang-undangan dan pengaplikasian hukum/peraturan, dengan tujuan (umum) yang mengarah pada upaya mewujudkan kesejahteraan atau kemakmuran masyarakat (warga negara) ${ }^{43}$

Bertolak dari kedua istilah asing tersebut, maka istilah kebijakan hukum pidana dapat pula disebut dengan istilah politik hukum pidana. Dalam kepustakaan asing istilah politik hukum pidana ini sering dikenal dengan berbagai istilah, antara lain penal policy, criminal law policy atau staftrechtspolitiek.. ${ }^{44}$

Dalam Kamus Besar Bahasa Indonesia memberikan arti terhadap istilah politik dalam 3 (tiga) batasan pengertian, yaitu : ${ }^{45}$

1) Pengetahuan mengenai ketatanegaraan (seperti sistem pemerintahan, dasar-dasar pemerintahan);

2) Segala urusan dan tindakan (kebijakan, siasat dan sebagainya);

3) Cara bertindak (dalam menghadapi atau menangani suatu masalah) kebijakan.

Mengkaji politik hukum pidana akan terkait dengan politik hukum. Politik hukum terdiri atas rangkaian kata politik dan hukum. Menurut Sudarto, istilah politik dipakai dalam berbagai arti, yaitu : ${ }^{46}$

1) Perkataan politiek dalam bahasa Belanda, berarti sesuatu yang berhubungan dengan negara;

2) Berarti membicarakan masalah kenegaraan atau berhubungan dengan negara.

Menurut Mahfud, politik hukum sebagai legal policy yang akan atau telah dilaksanakan secara nasional oleh Pemerintah, yang meliputi : ${ }^{47}$

${ }^{43}$ Barda Nawawi Arief, Bunga Rampai Kebijakan Hukum Pidana, PT. Citra Aditya Bakti (Bandung, 2010), Halaman : 23-24.

${ }^{44}$ Aloysius Wisnubroto, Kebijakan Hukum Pidana dalam Penanggulangan Penyalahgunaan Komputer, Universitas Atmajaya (Yogyakarta, 1999), Halaman : 10.

${ }^{45}$ Departemen Pendidikan dan Kebudayaan, Kamus Besar Bahasa Indonesia, Balai Pustaka (Jakarta, 1998), Halaman : 780.

${ }^{46}$ Teguh Prasetyo dan Abdul Halim Barkatullah, Politik Hukum Pidana : Kajian Kebijakan Kriminalisasi dan Dekriminilisasi, Pustaka Pelajar (Yogyakarta, 2005), Halaman : 11.

${ }^{47}$ Moh. Mahfud M.D, Pergulatan Politik dan Hukum di Indonesia, Gama Media (Yogyakarta, 1999), Halaman : 9. 
1) Pembangunan hukum yang berintikan pembuatan dan pembaharuan terhadap materi- materi hukum agar dapat sesuai dengan kebutuhan;

2) Pelaksanaan ketentuan hukum yang telah ada termasuk penegasan fungsi lembaga dan pembinaan para penegak hukum.

Dari definisi tentang kebijakan hukum pidana yang telah diuraikan sebelumnya, sekilas tampak bahwa kebijakan hukum pidana identik dengan pembaharuan perundang-undangan hukum pidana yaitu substansi hukum, bahkan sebenarnya ruang lingkup kebijakan hukum pidana lebih luas daripada pembaharuan hukum pidana. Hal ini disebabkan karena kebijakan hukum pidana dilaksanakan melalui tahap-tahap konkretisasi/operasionalisasi/fungsionalisasi hukum pidana yang terdiri dari ${ }^{48}$

1) Kebijakan formulatif/legislatif, yaitu tahap perumusan/penyusunan hukum pidana;

2) Kebijakan aplikatif/yudikatif, yaitu tahap penerapan hukum pidana;

3) Kebijakan administratif/eksekutif, yaitu tahap pelaksanaan hukum pidana.

Kebijakan hukum pidana tidak dapat dipisahkan dari sistem hukum pidana. Dalam hal ini, Marc Ancel menyatakan bahwa setiap masyarakat yang terorganisir memiliki sistem hukum yang terdiri dari peraturan-peraturan hukum pidana beserta sanksinya, suatu prosedur hukum pidana dan suatu mekanisme pelaksanaan pidana. ${ }^{49}$

Selanjutnya, A.Mulder mengemukakan bahwa kebijakan hukum pidana ialah garis kebijakan untuk menentukan : ${ }^{50}$

1) Seberapa jauh ketentuan-ketentuan pidana yang berlaku perlu diubah atau diperbaharui;

2) Apa yang dapat diperbuat untuk mencegah terjadinya tindak pidana;

3) Cara bagaimana penyidikan, penuntutan, peradilan dan pelaksanaan pidana harus dilaksanakan.

Dengan demikian kebijakan hukum pidana berkaitan dengan proses penegakan hukum (pidana) secara menyeluruh. Oleh sebab itu, kebijakan hukum pidana diarahkan pada konkretisasi/operasionalisasi/funsionalisasi hukum pidana material (substansial), hukum pidana formal (hukum acara pidana) dan hukum pelaksanaan pidana. Selanjutnya kebijakan hukum pidana dapat dikaitkan dengan tindakan-tindakan :51

1) Bagaimana upaya pemerintah untuk menanggulangi kejahatan dengan hukum pidana;

2) Bagaimana merumuskan hukum pidana agar sesuai dengan kondisi masyarakat;

3) Bagaimana kebijakan pemerintah untuk mengatur masyarakat dengan hukum pidana;

4) Bagaimana menggunakan hukum pidana untuk mengatur masyarakat dalam rangka mencapai tujuan yang lebih besar.

Penggunaan hukum pidana dalam mengatur masyarakat (lewat peraturan perundang-undangan) pada hakekatnya merupakan bagian dari suatu langkah kebijakan (policy). Operasionalisasi kebijakan hukum pidana dengan sarana penal (pidana) dapat dilakukan melalui proses yang terdiri atas tiga tahap, yakni : 52

1) Tahap formulasi (kebijakan legislatif);

2) Tahap aplikasi (kebijakan yudikatif/yudisial);

3) Tahap eksekusi (kebijakan eksekutif/administratif).

Berdasarkan hal di atas, kebijakan hukum pidana terkandung di dalamnya tiga kekuasaan/kewenangan, yaitu kekuasaan legislatif/formulatif berwenang dalam hal menetapkan atau merumuskan perbuatan apa yang dapat dipidana yang berorientasi pada permasalahan pokok dalam hukum pidana meliputi perbuatan yang bersifat melawan hukum, kesalahan/pertanggungjawaban pidana dan sanksi apa yang dapat dikenakan oleh pembuat undang-undang. Dengan demikian diharapkan tahap ini mampu mengimbangi perkembangan kejahatan ataupun tindak pidana merek, kebijakan hukum pidana yang di buat legislatif melalui undang-undang yang di terbitkannya mampu mencegah peluku tindak pindana merek, baik itu pada peningkatan hukuman maupun pada perluasn terhadap tindak pidana merek.

Tahap aplikasi merupakan kekuasaan dalam hal menerapkan hukum pidana oleh aparat penegak hukum atau pengadilan, dan tahapan eksekutif/administratif dalam melaksanakan hukum pidana oleh aparat pelaksana/eksekusi pidana. ${ }^{53}$ Dalam tahap ini kita dapat melihat bahwa penerapan hukum oleh

${ }^{48}$ Barda Nawawi Arief, Bunga Rampai ..., Op Cit, Halaman : 24.

${ }^{49}$ Ibid, Halaman : 28-29.

${ }^{50}$ Aloysius Wisnubroto, Op Cit, Halaman : 12.

${ }^{51}$ Ibid, Halaman : 14.

${ }^{52}$ Barda Nawawi Arif, Masalah Penegakan Hukum dan Kebijakan Hukum Pidana dalam Penanggulangan Kejahatan, Kencana Media Group (Jakarta, 2007), Halaman : 78-79.

${ }^{53}$ Ibid, Halaman : 80. 
aparat penegak hukum terkait dengan tindak pidana merek haruslah melihat fakta-fakta dilapangan, dengan demikian penegakan hukum terhadap merek dapat menjadi lebih baik.

Dilihat dari perspektif hukum pidana, maka kebijakan formulasi harus memperhatikan harmonisasi internal dengan sistem hukum pidana atau aturan pemidanaan umum yang berlaku saat ini. Tidaklah dapat dikatakan terjadi harmonisasi/sinkronisasi apabila kebijakan formulasi berada diluar sistem hukum pidana yang berlaku saat ini.

Kebijakan formulasi merupakan tahapan yang paling stategis dari penal policy karena pada tahapan tersebut legislatif berwenang dalam hal menetapkan atau merumuskan perbuatan apa yang dapat dipidana yang berorientasi pada permasalahan pokok hukum pidana meliputi perbuatan yang bersifat melawan hukum, kesalahan, pertanggung jawaban pidana dan sanksi apa yang dapat dikenakan. Oleh karena itu, upaya penanggulangan kejahatan bukan hanya tugas aparat penegak hukum tetapi juga tugas aparat pembuat undang-undang (aparat legislatif). ${ }^{54}$

b. Kebijakan Hukum Non Penal

Pembinaan dan penggarapan kesehatan jiwa masyarakat memang tidak berarti semata-mata kesehatan rohani/mental, tetapi juga kesehatan budaya dan nilai-nilai pandangan hidup masyarakat. Ini berarti penggarapan kesehatan masyarakat atau lingkungan sosial yang sehat (sebagai salah satu upaya nonpenal dalam strategi politik kriminal), tidak hanya harus berorientasi pada pendekatan religius tetapi juga berorientasi pada pendekatan identitas budaya nasional. Dilihat dari sisi upaya nonpenal ini berarti, perlu digali, dikembangkan dan dimanfaatkan seluruh potensi dukungan dan dan partisipasi masyarakat dalam upaya untuk mengektifkan dan mengembangkan "extra legal system" atau "informal and traditional system" yang ada di masyarakat.

Upaya non penal yang paling strategis adalah segala upaya untuk menjadikan masyarakat sebagai lingkungan sosial dan lingkungan hidup yang sehat (secara materiil dan immateriil) dari faktor faktor kriminogen. Ini berarti, masyarakat dengan seluruh potensinya harus dijadikan sebagai faktor penangkal kejahatan atau faktor "antikriminogen" yang merupakan bagian integral dari keseluruhan politik kriminal. Disamping upaya-upaya non penal dapat ditempuh dengan menyehatkan masyarakat lewat kebijakan sosial dan dengan mengali berbagai potensi yang ada di dalam masyarakat itu sendiri, dapat pula upaya non penal itu digali dari berbagai sumber lainnya yang juga mempunyai potensi efekpreventif.

Sumber lain itu misalnya, media pers/media massa, pemanfaatan kemajuan teknologi (dikenal dengan istilah "techno-prevention") dan pemanfaatan potensi efek-preventif dari aparat penegak hukum. Mengenai yang terakhir ini, Prof. Sudarto pernah mengemukakan, bahwa kegiatan patroli dari polisi yang dilakukan secara kontinu termasuk upaya non penal yang mempunyai pengaruh preventif bagi penjahat (pelanggar hukum) potensial. Sehubungan dengan hal ini, kegiatan razia/operasi yang dilakukan kepolisian di beberapa tempat tertentu dan kegiatan yang berorientasi pada pelayanan masyarakat atau kegiatan komunikatif edukatif dengan masyarakat, dapat pula dilihat sebagai upaya non penal yang perlu diefektifkan.

Fungsi hukum di dalam pembangunan adalah sebagai sarana pembaharuan masyarakat. Hal ini didasarkan pada anggapan bahwa adanya ketertiban dalam pembangunan, merupakan sesuatu yang dipandang penting dan sangat diperlukan.Upaya non penal merupakan kerangka pembangunan hukum nasional yang akan dating(ius constituendum). Pencegahan kejahatan harus mampu memandang realitas sosial masyarakat, hukum sebagai panglima harus mampu menciptakan suatu tatanan sosial melalui kebijakan sosial. ${ }^{55}$

Pembinaan bidang hukum harus mampu mengarahkan dan menampung kebutuhan-kebutuhan hukum sesuai dengan kesadaran hukum rakyat yang berkembang ke arah modernisasi menurut tingkat kemajuan pembangunan di segala bidang sehingga tercapai ketertiban dan kepastian hukum sebagai prasarana yang harus ditujukan ke arah peningkatan pembinaan kesatuan bangsa, sekaligus berfungsi sebagai sarana menunjang perkembangan modernisasi dan pembangunan yang menyeluruhpembangunan hukum pada hakikatnya mencakup pembinaan hukum serta pembaharuan hukum. Pembinaan hukum pada hakikatnya berarti usaha-usaha untuk lebih menyempurnakan hukum yang sudah ada, sehingga sesuai dengan perkembangan masyarakat. ${ }^{56}$

\author{
${ }^{54}$ Ibid. Halaman : 34 \\ ${ }^{55}$ Lawrence M.Friedman, Sistem Hukum, Diterjemahkan oleh M. Khozim, Cet.ke-4, Nusa Media,
} Bandung, 2011, Halaman 87.

${ }^{56}$ Barda Nawawi, Bunga Rampai Kebijakan Hukum Pidana (Perkembangan Penyusunan Konsep KUHP Baru), Cet.Ke-2, Kencana, Jakarta, 2010. 
Hukum sesungguhnya merupakan fasilitasi interaksi antara manusia yang bertujuan untuk mencapai keteraturan kehidupan sosial sehingga kaidah-kaidah hukum yang akan diterapkan haruslah memiliki kerangka falsafah, nilai kebudayaan dan basis sosial yang hidup di masyarakat.

Satjipto Rahardjo mengatakan, hukum itu tertanam ke dalam dan berakar dalam masyarakatnya. Setiap kali hukum dan cara berhukum dilepaskan dari konteks masyarakatnya maka kita akan dihadapkan pada cara berhukum yang tidak substansil. Hukum itu merupakan pantulan dari masyarakatnya, maka tidak mudah memaksa rakyat untuk berhukum menurut cara yang tidak berakar pada nilai-nilai dan kebiasaan yang ada dalam masyarakat itu. Selalu ada tarik menarik antara hukum yang berlaku dan diberlakukan dengan masyarakatnya. Hukum bukan institutif yang steril dar satu skema yang selesai. Hukum tidak ada di dunia abstrak melainkan juga berada dalam kenyataan masyarakat. ${ }^{57}$

Optimalisasi jalur non penal sejalan dengan cita-cita bangsa dan tujuan negara, seperti yang tercantum dalam Pembukaan Undang-undang Dasar Republik Indonesia Tahun 1945 yang memuat Pancasila. ${ }^{58}$ Segala bentuk pembangunan harus berangkat dari nilai-nilai Pancasila, karena pada hakikatnya pancasila merupakan tonggak konvergensi berbagai gagasan dan pemikiran mengenai dasar falsafah kenegaraan yang didiskusikan secara mendalam oleh para pendiri negara.

Pancasila menjadi kesepakatan luhur (modus vivendi) yang kemudian ditetapkan sebagai dasar ideologi negara. Dalam hal ini, upaya non penal dalam pencegahan tindak pidana merupakan salah satu aspek cita-cita Pancasila, Pancasila menjadi dasar rasional mengenai asumsi tentang hukum yang akan dibangun sekaligus sebagai orientasi yang menunjukan kemana bangsa dan negara harus dibangun. ${ }^{59}$

c. Formulasi kedepan terhadap Undang-undang Merek.

Salah satu perkembangan di bidang Merek adalah munculnya pelindungan terhadap tipe Merek baru atau yang disebut sebagai Merek nontradisional. Dalam undang-undang ini lingkup Merek yang dilindungi meliputi pula Merek suara, Merek tiga dimensi, Merek hologram, yang termasuk dalam kategori Merek nontradisional tersebut.

Selanjutnya, beberapa penyempurnaan untuk lebih meningkatkan pelayanan kepada masyarakat Pemohon Merek. Untuk lebih memudahkan bagi Pemohon dalam melakukan pendaftaran Merek perlu dilakukan beberapa revisi atau perubahan berupa penyederhanaan proses dan prosedur pendaftaran Merek. Adanya pengaturan tentang persyaratan minimum Permohonan akan memberikan kemudahan dalam pengajuan Permohonan dengan cukup mengisi formulir Permohonan, melampirkan label atau contoh Merek yang dimohonkan pendaftaran, dan membayar biaya Permohonan. Dengan memenuhi kelengkapan persyaratan minimum Permohonan tersebut, suatu Permohonan Merek akan diberikan Tanggal Penerimaan atau filing date. $^{60}$

Perubahan terhadap alur proses pendaftaran Merek dalam undang-undang ini dimaksudkan untuk lebih mempercepat penyelesaian proses pendaftaran Merek. Dilaksanakannya pengumuman terhadap Permohonan sebelum dilakukannya pemeriksaan substantif dimaksudkan agar pelaksanaan pemeriksaan substantif dapat dilakukan sekaligus jika ada keberatan dan/atau sanggahan sehingga tidak memerlukan pemeriksaan kembali.

Berkenaan dengan Permohonan perpanjangan pendaftaran Merek, pemilik Merek diberi kesempatan tambahan untuk dapat melakukan perpanjangan pendaftaran Mereknya sampai 6 (enam) bulan setelah berakhirnya jangka waktu pendaftaran Merek. Ketentuan ini dimaksudkan agar pemilik Merek terdaftar tidak dengan mudah kehilangan Hak atas Mereknya sebagai akibat adanya keterlambatan dalam mengajukan perpanjangan pendaftaran Merek.

Selain itu, untuk lebih memberikan pelindungan hukum terhadap pemilik Merek terdaftar dari adanya pelanggaran Merek yang dilakukan oleh pihak lain, sanksi pidana terhadap pelanggaran Merek tersebut diperberat khususnya yang mengancam kesehatan manusia, lingkungan hidup, dan dapat mengakibatkan kematian. Mengingat masalah Merek terkait erat dengan faktor ekonomi, dalam Undang-undang ini sanksi pidana denda diperberat. Salah satu hal yang diatur dalam Undang-undang ini adalah tentang Indikasi Geografis, mengingat Indikasi Geografis merupakan potensi nasional yang dapat menjadi komoditas unggulan, baik dalam perdagangan

\footnotetext{
${ }^{57}$ Ibid. Halaman : 34

${ }^{58}$ M. Hamdan, Politik Hukum Pidana, Raja Grafindo Persada, Jakarta, 1997, Halaman : 23.

${ }^{59}$ Susanto, Anthon F, Wajah Peradilan Kita, Refika Aditama, Bandung, 2004, Halaman 15.

${ }^{60}$ Tim Visi Yustisia, Op Cit, Halaman 76.
} 
domestik maupun internasional. Oleh karena itu, Undang-undang ini ditetapkan dengan nama Undang-undang Merek dan Indikasi. ${ }^{61}$

Kedepan harapannya aturan terkait dengan merek ini harus mampu mengimbangi kemajuan zaman dan tekhnologi, kejahan dan atau tindak pidana terhadap merek ini terkesan biasa saja, oleh karena itu perlu kiranya pemerintah sebagai eksekutif dan Dewan Perwakilan Rakyat sebagai legislatif membuat aturan terkait dengan merek yang lebih sempurna lagi, yaitu meningkatkan sanksi pidana terhadap pelanggaran merek, baik pelanggaran terhadap persamaan pada pokoknya , maupun pelanggaran terhadap persamaan pada keseluruhan.

\section{KESIMPULAN DAN SARAN}

a. Kesimpulan

1. Pengaturan hukum pidana mengenai perbuatan penggunan merek yang sama pada pokoknya di atur pada Bab XVIII Pasal 100-101 undang-undangNo. 20 tahun 2016 tentang merek dan indikasi geografis perubahan atasundang-undang No. 15 tahun 2001 tentang merek. Kehadiran undang-undang merek 2016 adalah untuk menyempurnakan perlindungan kepada pemilik merek dan juga memberikan penyesuaian terhadap perkembangan kekayaan intelektual di Indonesia.

2. Tindak pidana merek umumnya dilakukan dengan kesengajaan. Sehingga dalam diri pelaku, baik orang perorangan maupun pengurus korporasi dalam dirinya melekat suatu kesengajaan untuk melakukan tindak pidana di bidang merek, konsep pertanggungjawaban pidana di bidang merek dalam Sistem Hukum PidanaIndonesia, tidak dapat dilepaskan dengan predikat ataupun subjek hukum pelaku tindak pidana di bidang merek. pertangungjawaban pidana terkait dengan tindak pidana yang penulis kaji, bahwa harusnya terdakwa dinyatakan melakukan sebuah tindak pidana karena merek yang dimiliki terdakwa berupa VIM KHO mengandung bahan pemutih yang sejatinya sama pada pokoknya dengan merek VIN KHO milik korban, dari bukti yang ada ternyata merk VIM KHO milik terdakwa telah terdaftar di Dirjen Hak Cipta Paten dan Merek sebagaimana sertifikat No. 335057 tanggal 09 Juni 1994 atas nama terdakwa lebih dahulu dari merek VIN KHO No. 559997 tanggal 21 Januari 2004 atas nama korban, namun kegunaan dan fungsi merek yang terdakwa daftarkan berbeda dengan kegunaan dan fungsi merek terdakwa yang beredar di pasaran, sementara pemilik merek VIN KHO memiliki kegunaan dan fungsinya yang sesuai dengan sertifikt merek yang di terbitkan oleh Dirjen Haki.

3. Kebijakan hukum pidana (penal police) terkandung di dalamnya tiga kekuasaan/kewenangan, yaitu kekuasaan legislatif/formulatif berwenang dalam hal menetapkan atau merumuskan perbuatan apa yang dapat dipidana yang berorientasi pada permasalahan pokok dalam hukum pidana meliputi perbuatan yang bersifat melawan hukum, kesalahan/pertanggungjawaban pidana dan sanksi apa yang dapat dikenakan oleh pembuat undang-undang. Dengan demikian diperhatikannya tahap ini mampu mengimbangi perkembangan kejahatan ataupun tindak pidana merek dan itikad tidak baik terhadap merek, kebijakan hukum pidana yang di buat legislatif melalui undang-undang yang di terbitkannya mampu mencegah peluku tindak pindana merek, baik itu pada peningkatan hukuman maupun pada perluasan terhadap tindak pidana merek. Tahap aplikasi oleh aparat penegak hukum atau pengadilan, dan tahapan eksekutif/administratif dalam melaksanakan hukum pidana oleh aparat pelaksana/eksekusi pidana. Dalam tahap ini kita dapat melihat bahwa penerapan hukum oleh aparat penegak hukum terkait dengan tindak pidana merek haruslah melihat fakta-fakta dilapangan, dengan demikian penegakan hukum terhadap merek dapat menjadi lebih baik. Di berengi dengan hal demikian, kebijakan hukum non penal juga sagat menentukan dalam perkembangan hukum merek di indonesia, dengan upaya penyuluhan dan pengawasan yang optimal serta penambahan personil dalam pengawasan dan pencegahan tidak pidana merek merupakan hal yang harus di perhatikan.

b. Saran

1. Diharapkan agar pengaturan hukum terkait dengan penggunaan merek yang sama pada pokoknya di indonesia memiliki kejelasan dan kelengkapan, karena jika melihat perkembangan

61 Diakses Melalui: http://www.madaniyah.com/undang-undang-nomor-20-tahun2016.html?page=2, Pada ari senin, tanggal 12 Maret 2018, Pukul 22.00 WIB. 
dunia usaha ataupun perkembangan bisnis di indonesia, merek merupakan hal yang memang harus menjadi perhatian pemerintah, guna melindungi pebisnis lokal dan internasional yang memiliki usaha di negri ini, hal ini juga merupakan hal yang sangat menjadi perhatian kita bersama dikarenakan dunia usaha dan bisnis merupakan salah satu pemasok pajak tersebesardi indonesia.

2. Disarankan agar perbuatan penggunaan merek yang sama pada pokonya tanpa izin dapat berkurang dengan adanya pertanggungjawaban pidana yang dibebankan kepada pelaku tindak pidana dan membuat pelaku tindak pidana merek tidak menjamur di indonesia, karena akan merusak iklim bisnis di indonesia.

3. Disarankan agar terjadi banyak pembaharuan dalam hukum pidana merek ini, formulasi khusus yang di sesuaikan dengan perkembangan zaman dan teknologi, dan hal ini haruslah menjadi perhatian bagi pemerintah sebagai eksekutif dan Dewan Perwakilan Rakyat sebagai legislatif dalam proses pembuatan aturan hukum, hal ini merupan fokus kita bersama bagaimana harusnya aturan hokumpidana merek di ciptakan dengan sebaik baiknya dan sesuai denganperkembangan zaman dan tekhnologi dengan meningkatkan pengawasan khusus terhadap pendataran dan pemeriksaan awal merek yang akan di daftarkan serta meningkatkan ancaman pidana bagi pelaku tindak pidana merek.

\section{DAFTAR PUSTAKA}

Anonym. 2017. “Apakah Logo Terdaftar Perusahaan Otomatis Menjadi Merek”, Melalui www.hukumonline.com, diakses Minggu, 5 Maret 2017.

Arief, Barda Nawawi. 2010. Bunga Rampai Kebijakan Hukum Pidana, PT. Citra Aditya Bakti . Bandung.

Chazawi, Adami. 2007. Tindak pidanan Hak Atas Kekayaan Intelektual (HAKI), Banyumedia, Malang.

Ediwarman, 2009. Monograf Metode Penelitian Hukum, edisi ke II, Medan.

Fuady, Munir. 2007. Dinamika Teori Hukum, Jakarta: GHalamania Indonesia.

Hadjono, Philipus M. 2007. Perlindungan hukum bagi HAKIdi indonesia edisi khusus penerbitan perdapan. Ciptas Swada. Jakarta.

Ibrahim, Jhonny. 2006. Teori Dan Metedologi Penelitian Hukum Normatif, Pustaka Pelajar, Jakarta.

Moleong, Lexy J. 2004. Metodologi Penelitian Kualitatif,PT. Remaja Rosda Karya, Bandung.

Mukti Fajar N.D dan Yulianto Achmad. 2010. Dualisme Penelitian Hukum Normatif dan Empiris. Pustaka Pelajar, Yogyakarta.

Painduri Nasution, Rahmi Jened. 2015. Interface Hukum Kekayaan Intelektual dan Hukum Persaingan Penyalahgunaan HKI. PT. Raja Grafindo Persada, Jakarta.

Sutedi, Adrian. 2013. Hak Atas Kekayaan Intelektual. Sinar Grafika,Jakarta.

Soerjono dan Sri. 1995. Penelitian Hukum Normatif Suatu Tinjauan Singkat, Jakarta: RajaGrafindo.

Tim Lindsey, dkk (ed), 2011. Hak Kekayaan Intelektual Suatu Pengantar. PT Alumni, Bandung. Anonym, 2017. “Apakah Logo Terdaftar Perusahaan Otomatis Menjadi Merek”, Melalui www.hukumonline.com, diakses Minggu, 5 Maret 2011.

Tim Redaksi Tatanusa, Himpunan Putusan-Putusan Mahkamah Agung Dalam Perkara Hak Kekayaan Intelektual, Tatanusa, Jakarta.

Waluyo, Bambang. 1996. Penelitian Hukum Dalam Praktek, Jakarta: Sinar Grafika.

Yustisia, Tim Visi. 2015. Panduan Resmi Hak Cipta dari Mendaftar, Melindungi, hingga Menyelesaikan Sengketa. Visimedia, Jakarta. 